University of Wollongong

Research Online

Faculty of Business - Papers (Archive)

Faculty of Business and Law

$1-1-2014$

Organizational change within charities: Improved performance via introduction of market orientation and other strategic orientations

Paul Chad

University of Wollongong, pchad@uow.edu.au

Follow this and additional works at: https://ro.uow.edu.au/buspapers

Part of the Business Commons

Research Online is the open access institutional repository for the University of Wollongong. For further information contact the UOW Library: research-pubs@uow.edu.au 


\title{
Organizational change within charities: Improved performance via introduction of market orientation and other strategic orientations
}

\begin{abstract}
Market orientation is recognised as the key strategic orientation enabling for-profit organizations to gain improved performance. Adopting such an orientation can also aid nonprofit charities facing pressure to become more businesslike due to increasing competition in the current global environment. Knowledge regarding exactly how charities can change is however highly under-researched. Based upon examination of multiple case studies of charities that underwent organisational change to improve performance, the change management process is analysed using a discourse transformation framework to identify how charity managers successfully introduced new strategic orientations dominated by a market orientation. A "checklist" is developed that offers nonprofit charity managers valuable insights to assist performance improvement. Few previous papers have studied the process by which management of charities can successfully implement change towards market orientation and aspects of other strategic orientations. The paper also expands the use a discourse transformation in examining the change management process within charities.
\end{abstract}

\section{Keywords}

orientation, charities, within, change, organizational, other, market, introduction, orientations, via, strategic, performance, improved

\section{Disciplines \\ Business}

\section{Publication Details}

Chad, P. (2014). Organizational change within charities: Improved performance via introduction of market orientation and other strategic orientations. International Review on Public and Nonprofit Marketing, 11 (1), 89-113. 
Organizational Change Within Charities: Improved Performance Via Introduction of Market Orientation and Other Strategic Orientations.

Dr Paul Chad

Centre for Research in Socially Responsible Marketing

School of Management and Marketing

University of Wollongong

Northfields Ave, Wollongong

New South Wales, 2522

Australia

Phone: +61242214413

Fax: $\quad+61242214154$

Email: pchad@uow.edu.au 
Organizational Change Within Charities: Improved Performance Via Introduction of Market Orientation and Other Strategic Orientations.

\begin{abstract}
Market orientation is recognised as the key strategic orientation enabling for-profit organizations to gain improved performance. Adopting such an orientation can also aid nonprofit charities facing pressure to become more businesslike due to increasing competition in the current global environment. Knowledge regarding exactly how charities can change is however highly under-researched. Based upon examination of multiple case studies of charities that underwent organisational change to improve performance, the change management process is analysed using a discourse transformation framework to identify how charity managers successfully introduced new strategic orientations dominated by a market orientation. A "checklist" is developed that offers nonprofit charity managers valuable insights to assist performance improvement. Few previous papers have studied the process by which management of charities can successfully implement change towards market orientation and aspects of other strategic orientations. The paper also expands the use a discourse transformation in examining the change management process within charities.
\end{abstract}

\title{
Keywords
}

Strategic orientation, market orientation, nonprofit, change management, charity 


\section{Introduction}

Market orientation (MO) is the key strategic orientation identified as assisting for-profit organisations improve performance (Kohli and Jaworski 1990; Narver and Slater 1990; Raju, Lonial and Crum 2011). Despite differences between the for-profit and nonprofit sectors, the generally positive linkage between performance and MO can be extended to the nonprofit sector (Gainer and Padanyi 2005; Kara et al. 2004; Shoham et al. 2006), but is lessresearched. Nonprofit organisations (NPOs) operate in a competitive environment (Blery et al. 2010) and are "facing strong environmental and market changes" (Costa et al. 2011, p. 473) and "increasing demands to become more efficient and effective" due to financial restraints and rising demand for their services (Ridder et al. 2012, p. 605). Charities, a major subset of the nonprofit sector, are confronted by similar economic pressures as any for-profit business (Clohesy 2003), need to adapt to survive (Choi 2012) and become more businesslike (McDonald 2007) with the aim of becoming more market-oriented.

Strategic orientations have been highly research over the years, particularly MO. There is however little research regarding the change management process that results in successful introduction of MO (Taghian 2010). The aim of this paper is thus to address this gap, also responding to the specific call for research regarding how nonprofit organisations “can best build and maintain MO” (Shoham et al. 2006, p. 470). This research also extends the literature by explicitly addressing the lack of practitioner perspectives (Cornelissen and Lock 2005, p. 166) characteristic of previous research regarding MO, and identifying "profiles of best practice to implement market orientation (Kirca et al. 2005). The research also contributes by responding to calls from Hakala (2011, p. 212) for "identifying the potential configurations of orientations, the ways in which they interact”. Therefore, this paper aims to: first, examine how management can successfully conduct change within 
traditional charity organisations to establish MO; and second, identify the possible existence of other strategic orientations also potentially present in the changed organisations.

This paper thus makes an important contribution to both theory and practice in the nonprofit literature. Adding to the sparse literature exploring charity change management towards a more businesslike orientation, the result of this research is valuable knowledge for management of charities and other NPOs seeking to improve the performance of their organisations. The research further contributes by progressing use of a discourse transformation perspective not typically utilised in examining the change management process within charities.

\section{Literature Review}

\subsection{Market orientation and other strategic orientations}

A strategic orientation can be defined as "guiding principles" influencing organisational "marketing and strategy-making activities" (Noble et al. 2002, p. 25) and these strategic dimensions are aimed at creating appropriate behaviours within an organisation for continuous superior performance (Narver and Slater 1990). The main three typically reported strategic orientations are market orientation (MO), entrepreneurial orientation (EO), and learning orientation (LO) (Liu and Fu 2011) with various other strategic orientations also reported in the literature. Significantly, MO is considered the key contributor to organisational performance compared to alternate strategic orientations (Grinstein 2008), and hence is the focus of the current paper. 
Based upon research within the for-profit sector, Kohli and Jaworski (1990) as well as Narver and Slater (1990) provide the seminal, theoretical foundations for MO. Kohli and Jaworski (1990) defined MO as consisting of three core components, namely company activities relating to market intelligence generation, dissemination and responsiveness across all functions. Narver and Slater (1990) took a culturally based behaviour perspective of the organisation and regarded an organisation's activities as containing three components, a customer-orientation, competitor orientation, and inter-functional co-ordination, all based upon generating long-term profit. Examining the range of MO views developed during the 1990’s, Lafferty and Hult (2001) identified four common "synthesis dimensions” of MO, namely (1) an emphasis on customers, (2) the importance of information, (3) interfunctional coordination, and (4) taking action. Relative to for-profit organizations, NPOs "are more complex" (Anheier, 2000, p. 16) and "ready-made management models carried over from the business world” (Anheier 2000, p. 8) are not appropriate for NPOs without modification. Subsequent MO research involving modification of the seminal MO models of Narver and Slater (1990) and Kohli and Jaworski (1990) to suit the nonprofit sector was conducted by Liao, Foreman and Sargeant (2001), González, Vijande and Casielles (2002), Sargeant, Foreman and Liao (2002) and more recently Duque-Zuluaga and Schneider (2008). A key aspect of the nonprofit MO models included identification of multiple stakeholders such as beneficiaries/recipients, donors/resource providers as well as both paid and volunteer employees.

EO is generally accepted as containing three key components - the willingness to take business related risks, the willingness to be proactive in competing against other organisations, and willingness to innovate (Covin and Slevin 1989; Naman and Slevin 1993). Risk taking relates to the willingness of management to commit resources to new projects, and incur debt to pursue opportunities (Lumpkin and Dees 1996), proactiveness relates to 
taking the initiative in pursuing market opportunities (Baker and Sinkula 2009), and innovativeness can be regarded as willingness to support creativity and experimentation in development of new products, adoption of technology, and internal processes and procedures (Lumpkin and Dees 1996).

LO is the "organizational-wide activity of creating and using knowledge to enhance competitive advantage" (Calantone et al. 2002, p. 516) and hence is the extent to which an organisation obtains and shares information regarding customer needs, the marketplace, competitors and also new product creation (Calantone et al. 2002). LO typically involves questioning the manner in which an organisation operates and aiming to "think outside the box” (Baker and Sinkula 1999a, p. 413). Baker and Sinkula (1999b) consider LO consists of three dimensions - commitment to learning, shared vision and open mindedness, whereas Calantone Cavusgil and Zhao (2002) add a fourth dimension of intra-organisational knowledge sharing.

Other strategic orientations seemingly less mentioned in the marketing literature include the following - Resource orientation (RO) is based upon the resource-based view and defined as the extent to which an organisation creates the necessary behaviours to identify, accumulate, and deploy unique and valuable resource bundles that create superior value and sustainable competitive advantage (Paladino 2006). RO can be divided into three components - uniqueness, synergy and dynamism. The aim is to possess unique resources that are difficult to replicate by competitors, utilise and gain benefit from the resources across the organisation in a synergistic manner, and utilise the resources in a dynamic manner so that they trigger learning and innovation within the organisation, and aid collaboration with stakeholders and enable achievement of efficiency and effectiveness in operations (Paladino 2007). Innovation orientation (IO) is the level to which organisations are open to, and proactively pursue new ideas in both technical and administrative activities (Hurley and Hult 1998) and risk taking is 
encouraged (although IO could be regarded as very similar to EO). Innovation can be regarded as a three-stage process involving acquisition, dissemination and subsequent use of new knowledge (Damanpour 1991). Technological orientation (TO) can be defined as "the ability and will to acquire a substantial technological background and use it in the development of new products” and is thus based upon an organisation's introduction and use of new technologies/products/innovation (Gatignon and Xuereb 1997, p. 78). Cost orientation (CO) relates to an organisation determining and analysing it's cost structures with the aim of reducing costs as much as possible in both primary and support functions (Olson et al. 2005).

Whilst various strategic orientations have been described in the literature, some can be regarded as having overlap with other strategic orientations. For example, LO can be regarded as related to aspects of $\mathrm{MO}$, namely information generation and use. Likewise, RO aims to stimulate learning and innovation, hence leading to potential development of LO and IO. Customer orientation and competitor orientation are also reported in the literature but are actually subsets of MO (Narver and Slater 1990). Similarly, interaction orientation, defined as the ability to interact with customers and "take advantage of information obtained" (Ramani and Kumar 2008, p. 27) can be regarded as part of intelligence generation/usage, thus also a subset of MO.

\subsection{Improving organisational performance}

An aim of most organisations is to improve performance. The various strategic orientations are suggested by the literature as assisting improve organisational performance. Within the range of strategic orientations available to for-profit organisations, MO has been shown to provide the most positive effect in improving organisational performance, over and above all other strategic orientations (Grinstein 2008). The benefit of MO "is well documented in 
scholarly research" with "overwhelming evidence” showing a positive relationship between MO and performance (Cano et al. 2004 p. 181). Likewise, meta-analysis by Kirca, Jayachandran and Bearden (2005, p. 37) concluded "market orientation has a positive impact on organizational performance”. The benefit has been well proven across a range of countries (Cano et al. 2004), in both for-profit (Shoham et al. 2005) and nonprofit organisations (Shoham et al. 2006) with the beneficial affect of MO confirmed in both the short and long term (Kumar et al. 2011). Significantly, meta-analysis of available MO research conducted by Shoham et al. (2006, p. 467) not only "supports the notion that MO affects VNPO's organizational performance positively" but also that "the MO-performance link is stronger in VNPOs than in for-profits”. It should however also be noted, “a few studies report a negative or non-significant relationship” (Cano et al. 2004, p. 181) between MO and performance. Whilst MO offers the most opportunity to improve organisational performance, adding proportions of various other strategic orientations can provide performance increases over and above that achieved solely by MO (Liu et al. 2012). The actual interaction of strategic orientations has been the topic of much research. For example, some studies suggest MO is required before other strategic orientations such as EO can be introduced (González-Benito et al. 2009) whilst other researchers suggest a purely complementary nature between MO and EO (Baker \& Sinkula 2009). In regards to LO, Mahmoud and Yusif (2012) consider LO outperforms MO in improving performance whereas Baker and Sinkula (1999a) regard LO and MO as complementary. In relation to IO, Calantone, Cavusgil and Zhao (2002) regard LO as an antecedent to innovation, similarly Hurley and Hult (1998) consider both MO and LO are antecedents to innovativeness. However, Modi (2012) regards innovation as complementary with MO. In regards to LO, it is considered an antecedent to MO (Slater and Narver 1995). 


\subsection{Implementation of strategic orientation}

Numerous research has been conducted regarding various aspects of strategic orientations. This research typically investigates the nature of, and the antecedents and consequences of these orientations. Research has tended to concentrate on MO given its dominant involvement in increasing organisational performance. Whilst models have been developed regarding the links between the various aspects of $\mathrm{MO}$, and research has examined the “barriers” to introducing MO (e.g. Harris, 1998, 2000; Harris and Ogbonna 2001; Mason and Harris 2005), a key literature gap is how to actually successfully implement MO. Barriers have been found to be both people-focused/cultural (Gainer and Padanyi 2005) and systemfocused (Harris and Piercy 1999) with Kirca, Jayachandran and Bearden (2005 p. 36), suggesting "internal processes have a greater influence than organisational structure variables”. Following a review of literature, van Raaij and Stoelhorst (2008) determined MO “enablers” to be based upon structure, process design, information systems, reward systems, leadership, behavioural norms and values as well as competence management.

This gap in our knowledge regarding how MO can successfully be introduced was investigated by Gebhardt et al. (2006) who suggested a four-stage MO implementation process of initiation, reconstitution, institutionalisation and maintenance. Shortly afterwards, Beverland and Lindgreen (2007, p. 430), stated the MO literature was "silent on the process of change involved in moving firms to a market orientation” and investigated the process in an industrial firm setting with a rigid framework based upon the change process model (unfreezing-movement-refreezing) of Lewin (1951). Despite this initial research regarding the process of implementing MO, Taghian (2010) considers the area still under-researched. Significantly, this previous research was conducted in the for-profit arena, with no examination of the nonprofit arena. 
Thus, whilst numerous research has been conducted regarding various aspects of strategic orientations (typically MO), there has been little research regarding the process by which MO can successfully be introduced into an organisation, particularly within the nonprofit charity sector. This paper aims to address this gap. It is important to fill this gap as this will assist in increasing our knowledge to enable charities to conduct organisational change to improve performance, and thus be in a better position to perform their key role of assisting the wellbeing of society.

\section{Research Approach.}

This research involves case studies of three charities that conducted organisational change. Case studies enable "intensive examination ... of the phenomena of interest” (Malhotra 2007, p. 42). Multiple cases enable "more robust, generalisable, and testable theory than single-case research” (Eisenhardt and Graebner 2007, p. 27). Case study method is recognised and established within MO research (e.g. Yakimova and Beverland 2005). Likewise, multiple case studies have previously been utilised to examine changes within charities (e.g. Bennett and Sharmila 2011).

The paper assesses how charities change as management introduce new strategic orientations based on MO. To examine the change process in the charities, a discourse transformation framework has been utilised based upon Foucault's (1991, pp. 56-57) criteria for "detecting changes which affect discursive formations" namely, "displacement of boundaries", "the new position and role" of employees, the "new mode of functioning of language" and the "circulation" of the new discourse. The benefit of examining change via this discourse transformation framework is that the very process specifically assists in 
assessing, detecting and identifying what changes have occurred, how they occurred, and the reaction/effect upon employees within the organisation (the very people who make up the organisation and through which strategic orientations are delivered). Another benefit of such a framework is that it is relatively freeform and does not constrain examination of the change into a rigid framework such as Lewin's (1951) unfreezing-movement-freezing change process model.

Semi-structured, in-depth interviews utilising open-ended questions were conducted. Interviews were initially conducted with the Chief Executive Officer or equivalent, then with employees from all functional areas and at all levels of the organisation, from senior management to frontline employees and volunteers. Theoretical sampling of interviewees subsequently stopped upon saturation enabling "sufficient data for those arguments to be well grounded” (Wood and Kroger 2000, p. 81). All interviews were conducted by a single interviewer for consistency and were based upon guidelines suggested by Patton (2002) utilising an interview protocol (Yin 1994). Interview questions were structured around Foucault's (1991, pp. 56-57) framework for examining discourse change, coupled with questions aimed at identifying the levels of various strategic orientations within the changed organisations. A copy of the interview questions is contained in Appendix 1. Subsequent manual thematic analysis of interview transcripts was based upon guidelines recommended by Creswell (2003, see pp. 191-195), Patton (2002, see pp. 465-468) and Tesch (1990, see. pp. 142-145). The manual analysis provided a high level of "immersion" in the data (Wood and Kroger 2000). Electronic copies of the transcripts were read and re-read over a period of weeks to assist the researcher to assimilate and contemplate the data. Key data was highlighted, and researcher thoughts and notes were typed onto the transcripts. A list of various issues/topics was determined. Evidence of each issue/topic identified within individual transcripts was subsequently 'cut and pasted' into a 'master' document thus 
combining evidence from the individual participants. Topics were abbreviated into codes, and clustered if similar. High-level themes were then determined from the coded data. Interview transcripts were supplemented by other data sources including organisational documents, newsletters, annual reports, press releases, internet sites and researcher observation of organisational activities and physical evidence within each charity. Within-case, followed by cross-case analysis was conducted.

\section{Results and discussion}

\subsection{The case study organisations}

A criteria-based selection process (LeCompte \& Preissle 1993) was utilised to select the three case study organisations. The criteria utilised were - nonprofit charities, operating in the ‘community service and assistance’ sector, geographically based in South Eastern Australia, and having experienced an attempt to introduce organisational change in recent years (although the actual nature of the change was unknown). The level of success in introducing MO was not a consideration and indeed was not known at the time of case selection. For confidentiality, the case study organisations will be referred to by pseudonyms - "Darista", “Hestina” and "Jantida”.

"Darista" - Operating for over 150 years within the state of New South Wales in Australia, Darista is a church-based charity assisting people who are disadvantaged or living in poverty. The organisation operates with predominantly volunteer staff coupled with a small proportion of paid employees. Revenue is obtained predominantly from the sale of second-hand items from retail shopfronts, government grants, plus donations from the public 
and church members. The government grants are specifically received to operate various aged-care facilities and housing for the homeless. Darista has traditionally operated with an extremely de-centralised structure, with each of the various branches given autonomy to conduct local operations as they saw fit. Key problems were an out-of-date corporate plan, poor economies of scale, lack of uniform service delivery, and variable branding across branches. Senior management, whilst well-meaning, lacked strong business skills. A change in management resulted in a new senior management team with appropriate corporate business skills. A new corporate strategic plan was developed and numerous changes introduced. Service delivery was improved based upon newly developed standard practices and procedures, accounting and reporting structures were formalised, a re-branding of the retail outlets occurred, and new public relations activities increased brand awareness. Income has increased markedly in the three years since the change, including a $45 \%$ increase in government funding following a strengthening of grant writing capability, a 103\% increase in bequests based upon targeting of potential clients via strong relationship marketing, and a $23 \%$ increase in sales of goods from the re-branded second-hand goods stores.

“Hestina” - Originating in the 1950’s, Hestina is a medium-sized Australian charity based in Sydney and operating nationally, employing over 100 staff and 40 volunteers. Hestina provides education and support services to children and adults suffering a specific mental impairment, raises awareness within the community and provides advocacy/lobbying to government. Eschewing government funding, Hestina relies upon self-generated funds and raises funds via an outbound call centre where staff contact potential donors and lottery ticket purchasers. Due to a deteriorating financial situation, in 2005 the CEO and the senior management team departed. A new CEO with assistance from a hand-selected new senior management team made changes towards providing "the foundation for service growth" (Hestina 2006, p. 2). The initial aim was to develop quality products, build organisation 
capability and introduce "new policies and procedures” (Hestina 2006, p. 3). There was "brand development ... expansion in services and fund-raising” (Hestina 2007, p. 4) and development of a "strong direct marketing capability” (Hestina 2007, p. 8). The overall strategy incorporated innovative services and delivery tools plus "commitment to quality services” (Hestina 2008, p. 5). Success of Hestina's new marketing strategy enabled a doubling of revenue within four years.

"Jantida"- As the community care arm of the Sydney (Australia) operations of a Christian-based church, Jantida assists people of all ages via a range of services including community care centres, counselling, disability and carer services, disaster recovery, chaplaincy and aged care. Jantida was struggling both financially and operationally and conducted a major re-structure in 2006. The incumbent CEO (a theologian) and all six general managers departed. A new CEO from the business world was recruited to reinvigorate the organisation. A strategic plan was developed following detailed analysis of the operating environment. Despite introduction of a more businesslike perspective, Jantida deliberately maintained a strong religious base. When the transformation commenced, Jantida had approximately 1,400 paid staff and 2,000 volunteers. Five years after the transformation, the level of paid staff has remained constant but volunteer levels have reduced by $50 \%$. Despite this reduction in volunteers, revenue has increased by $70 \%$, an indication of the increased efficiency and effectiveness of Jantida’s transformed operations.

A summary of key aspects of the three charity organisations is contained in Table I.

[Table I Here]

\subsection{Organisational change}


To assess the organisational change resulting in discourse transformation within each of the three case study organisations, Foucault's (1991, pp. 56-57) four criteria for “detecting changes which affect discursive formations” are utilised. In the following sections, comments obtained from the employee interviews are indicated in italics.

\subsubsection{Displacement of boundaries}

Prior to introduction of discourse change, all three organisations had been operating as traditional charities. Numerous volunteers were utilised, all three CEO’s were well-meaning and had social work/religious backgrounds but no formal business training. Change commenced when new CEO's at all three organisations reviewed service delivery programs resulting in modified, more efficient and new programs appropriate to addressing client needs. To fund the improved service delivery, all organisations revamped their revenue generation resources. In keeping with nonprofit organisations using multiple revenue sources (Fischer et al. 2011), the charities accessed a range of sources. Within Darista, greater targeting of government funds was utilised and capability to write high quality responses to government tender requests was obtained via recruitment of appropriately qualified and experienced personnel. Another major boundary change at Darista was introduction of strong relationship marketing activities by newly recruited staff to identify and target potential bequest providers. Innovative public relations campaigns, far less conservative than previously utilised were introduced and a re-branding of the second-hand stores focussed upon a new, younger target audience. Darista also introduced a strong digital media presence, with use of Twitter, Facebook and Linkedin.

For revenue generation, Hestina revamped their lottery sales operations. The transformation included installation of a predictive telephone dialling system into the outbound call centre to increase calling efficiency. Borrowing from the for-profit sector, 
"life-time value" analysis was introduced, regarded by the fund-raising manager as " $a$ brilliant tool to use". Likewise "recency, frequency, monetary which is commonly used in the direct marketing industry" was introduced and direct mail design was revamped to include “all sorts of funky stuff”. These tools enabled greater targeting and customising of contact materials to better meet the needs of existing and potential new lottery ticket purchasers.

Jantida developed new sources of revenue. Similar to Darista, capability and expertise to tender for government grants improved. Traditional direct marketing practices from the for-profit arena were introduced to improve fund-raising processes. Utilising a database of previous donor clients, regular appeal letters are sent out and now typically contain "good news” stories regarding service recipient client assistance. As indicated by a fundraiser- "we ask for money, give them a story and tell them why we need the money". Data-base segmentation was also introduced for more effective donor targeting. Similar to Hestina, the concept of customer life-time value has been introduced to identify the most attractive donors, which, as stated by Sargeant (2001) should be at the centre of relationship building with key donors.

\subsubsection{The new position and role of employees}

To achieve change, all three organisations increased the level of managerialism and professionalism. Managerialism is regarded as "dominance of management practices and ideas" (Meyer et al. 2013, p. 173). The new discourses contained components of "new managerialism" which has a "concern for efficiency, cost-effectiveness and competition" (Gewirtz \& Ball, 2000, p. 256) and is associated with "new icons such as outcomes and missions, and new rituals to enshrine them including corporate planning, performance evaluation and new fiscal accountability arrangements” (Sinclair 1996, p. 234). Associated to this were changes to staffing practices, typical of NPOs adapting "to the changing 
environment” (Ridder and McCandless 2010, p. 137). An increased level of reporting requirements (Waldon 2005) plus the need to pay more attention to the changing political environment (Austin 2003) has also influenced this new direction. As indicated by a Jantida employee, there was a "major cultural shift in the workplace".

Whilst volunteer staff are typical of the traditional charity discourse with a level of inter-changeability available between of volunteer and paid employees (Handy, Mook and Quarter, 2008), volunteers are typically seen as less professional and less expert (Salamon 1987). Identity conflict can occur (Kreutzer and Jäger 2011) which can shape views regarding both individual and organisational identities. The new discourses within each charity contain more professional, fully-paid staff. A Darista service provider commented that the charity had "made a conscious effort to employ people from different sectors with corporate backgrounds to bring that knowledge and to be able to apply it to in a not for profit sense". Similarly, the senior manager in charge of marketing indicated - "I've sort of shaken it up in that I've brought in some key positions, a fundraising manager, a digital marketing person, keeping an eye on the future in social media". Likewise, within service delivery a manager indicated - "I have seen an overall professionalisation ... there has been some big, big changes”.

Within each organisation, there has been a distinct shift by employees concerning the subject positions of service recipient clients. The increased professionalism has resulted in a new manner of service delivery, typified by a service provider at Darista who indicated - “it's now a whole suite of services including case management ... a whole holistic approach to dealing with the problem" of each client. This has been highly successful - "the quality of service to our clients has greatly, greatly improved in only three years, it's happened quite quickly”.

The introduction of professionalism within Darista initially received mixed acceptance - "the newer people who have degrees realise and think that professionalism 
coming in is a good thing [whereas some] individuals who have been working in Darista a long time have seen a lot of different ways of working come and go, and come from a time where things weren't very professional at all ... some just go with the flow, but other people would find it frightening”. An example of resistance to change within Darista was in the revenue generation area, where volunteers working in the second-hand stores didn't accept the new organisational direction and removed point-of-sale promotional material targeting a younger audience as "it was bringing too many young people into the shop". Employees were eventually won over when they realised the benefits to service delivery resulting from increased revenue generation. Likewise, within Hestina, the changes introduced were regarded as needed and positive, with a service provider commenting “I think we needed [the change]. It's impacted on my job description a lot but I think the organisation needed the changes”. Within Jantida, employees who resigned were replaced by new employees more appreciative and accepting of the new discourse. As indicated by a long-serving middle manager - "it was massive change, but in the last two years we can see the difference in a positive way”. A staff survey conducted two years after the discourse changes commenced indicated "widespread satisfaction about the changes". Employees regarded the changes as "pretty foreign to our way of working, but definite improvements long overdue" and "are appreciative of the new professionalism".

\subsubsection{The new mode of functioning of language}

Language can be used as a managerial tool to assist organisational change and new language was intentionally introduced to assist the discourse transformation. New words now commonplace within Darista are typical of a more businesslike discourse and include “strategic planning”, “vision”, “KPIs”, “style guides” and “relationship marketing”. New 
language identified within Jantida includes - “core business”, “risk management”, "key performance indicators", "strategic plan” and "strategic directions".

Care does however need to be taken when introducing language characteristic of a new discourse. Management within Hestina acknowledged they introduced the new discourse too quickly. As indicated by the new CEO - "we were talking a different language and some of the staff who have remained and worked their way through have now seen the light and actually say, well, 'we didn't even understand what you were talking about!' ... there was a whole new language ... I came here talking about needing to see our services as products and really needing to understand our markets, even those simple words, didn't mean anything to the people here”. A Hestina service provider indicated - "I ended up writing a glossary ... [we had] acute nursing background and had not had any previous exposure to service marketing or any marketing concept”.

\subsubsection{Circulation of the new discourse}

NPO marketing activities are regarded by some employees "as undesirable, too expensive, and a waste of stakeholders' money” (Helmig et al. 2004, p. 108). This is typically based upon a mis-understanding of exactly what marketing and a market orientation involves - and the resultant nett benefits to the organisation and stakeholders. New CEO’s were the initiators of change within each organisation. Frequent communication and shared understandings are a key to successful strategy implementation (Rapert, Velliquette and Garretson 2002). A key strategy introduced by Darista management to improve communications and disseminate information regarding the new organisation was introduction of an intranet, something taken for granted within most organisations, but previously distinctly lacking within Darista. Within Hestina, due to the relatively small size of the organisation and most employees being located on the same geographical site, the CEO took a more direct approach. Regular "action- 
tracking” meetings for all employees and fortnightly management meetings were conducted. A newly introduced intranet also assisted communication. Within Jantida, employees were invited to attend an initial strategic planning day. Involving employees in the change process from the start is an extremely effective strategy to gain 'buy-in' from employees. Employees are also a valuable resource (Jaskyte et al. 2010) which management should utilise to gain recommendations and suggestions throughout the change process. Numerous Jantida employees were originally dubious about attending the planning day but most were ultimately won over by the process which subsequently utilised cross-divisional committees and frequent employee intranet communications to progress the change process. A key process in winning over staff that may be dubious about the change was emphasis that the new mode of operation would provide improved benefits for service recipient clients, who, after all, are the raison d'être for charity organisations. The CEO's of each organisational required transformation leadership qualities to enable the building of an appropriate new organisational culture (Shiva and Suar 2012).

\subsection{Identification of strategic orientations}

The sections above show strong evidence that discourse transformation has occurred within each organisation. What, therefore, is the nature of the new discourses? All three organisations had operated as traditional charities but increasing competition resulted in a need for change.

The MO definition used in this paper is based on the research by Lafferty and Hult (2001) which integrates the range of views from key research, including the seminal research of Narver and Slater (1990) as well as Kohli and Jaworski (1990). In regards to MO, all dimensions now exist, albeit to differing extents within each organisation. The first key 
dimension of MO is "emphasis on customer" (Lafferty and Hult 2001). Whilst multiple stakeholders exist for any organisation, within charities, there is a "dual constituency" for “customers” - namely service recipient clients and donor/revenue-source clients (Padanyi \& Gainer 2004; Hsieh et al. 2008; Kinnell \& MacDougall 1997). Whilst the three charities studied have traditionally had a strong emphasis upon service recipient clients, there is now an even stronger emphasis, particularly assisted by highly trained and professional service delivery providers. Each organisation has revamped and improved services and delivery processes. This has resulted in more streamlined and more highly specific and focussed services better in tune with satisfying client needs. There has been a move towards offering a more holistic approach to service delivery within each of the three case organisations aimed at providing a better long-term solution for service recipient clients rather than band-aid solutions. There has also been increased "emphasis on customer" in regards to donor/revenue-source. Development of strong relationship marketing has occurred within Darista and Jantida when dealing with the government who provide funds. Hestina increased emphasis on their lottery customers via improved targeting and customisation of direct mailing materials to specific segments based upon customer lifetime value segmentation. Asked who was more important, service recipient clients or providers of funds, virtually all respondents within each of the three charities apportioned equal importance, with a typical comment being - "if we had no money we would still try and find a way to assist clients, but without donors we would not exist”.

The second key dimension of MO is "importance of information” (Lafferty and Hult 2001). Gathering, analysing and disseminating information (importance of information) are basic components of a market-oriented organisation. Hestina, for example, previously "wasn't geared up to even capture the data that it required". All organisations have introduced improved information gathering processes. Typically, numerous surveys have 
been introduced to gain feedback from service recipient clients and their family members, staff and funding bodies. Hestina developed a customer relationship management database segmented into cold calling and different tiers for existing donor clients and lottery buyers based on levels and frequency of donation. Weekly sales data are analysed as well as operator performances. As indicated by the senior manager in charge of fund-raising - "there is a history now for every lottery and every direct mail campaign that's been conducted. That is something that wasn't here before". There is also increased competitor analysis with each charity now subscribing to media monitoring services and other sources to gain knowledge of activities within their sector. For example, a senior Jantida employee indicated - "we take part in a benchmarking study that enables us to compare ourselves to other charities ... I also take every opportunity that I can to be involved in networking events and talk with people, just to anecdotally get some idea of what's going on". Increased emphasis upon information regarding various stakeholders (i.e. both service recipients and revenue providers) has thus increased.

The third key dimension of MO is "interfunctional coordination” (Lafferty and Hult 2001). This was previously extremely low in each organisation but has since improved markedly with a more structured and formal process now existing within all organisations. Darista previously had "bad internal communications" but introduction of an intranet greatly improved communications. Hestina "had the typical silo ... there were no internal communications". Hestina now has "regular general meetings" and they "try not to change the dates of those or postpone them". Similarly, within Jantida "it was actually frowned upon to actually talk to people from other divisions" but various cross-functional committees were formed to assist improved communications.

The first three dimensions of MO place employees in a better position for "taking action”, the fourth key dimension of MO (Lafferty and Hult 2001). All organisations were 
keen to convert their poorly performing charities into more businesslike and efficient operations, and appropriate action was introduced. For example, within Hestina, "the service itself was almost sort of dismantled" and rebuilt in an appropriate manner. The new service delivery could be summed up by the comment that - "we have [introduced] formal processes in documenting the needs assessment, individual service plans and measuring outcomes and being able to articulate what services we deliver, how we deliver them, in what time frame and what the expected outcomes are". Similarly, within Jantida, there were "changed staffing models in order to make it more efficient” and a more holistic approach to service delivery was taken "to meet people’s needs rather than just the band-aid type approach".

Whilst increase in MO was identified in all three charities, evidence of small levels of other orientations was also noted. Entrepreneurial orientation (innovativeness, risk taking and proactiveness) was noted within Darista in regards to the new public relations activities and the new direction for their second-hand stores. The new Hestina management were somewhat innovative in introducing various practices from the for-profit arena including direct marketing practices as well as investing in a new predictive telephone dialling system.

Learning orientation (commitment to learning, shared vision and open mindedness) was evident in both Hestina and Jantida. In Hestina, the CEO conducted specific training sessions to teach employees to concepts of business operations, and Jantida provided assistance to attend tertiary courses for some executives. Significantly, no assistance in learning was provided within Darista. In regards to technology orientation, Hestina introduced a state-of-the-art predictive dialling telephone system for the call centre.

Little other evidence of aspects of technology orientation were identified other than introduction of an intranet within both Darista and Hestina. All three organisations predominantly provide services - most of which need to be provided by people rather than 
machines. This is likely to be a key reason why a relatively low level of technology orientation exists within each organisation.

From a resource orientation perspective, the key resources needed by the organisations are revenue to support operations, appropriately trained employees, efficient administrative, operational and service delivery processes, as well as an appropriate level of volunteers. Each organisation recognised a deficiency of resources (mainly appropriately trained employees) and took steps to increase resources. Indeed, this was a key requirement to enable the change to occur within each organisation. Charities traditionally operate with a relatively low level of resources, and to move to a more businesslike and market-oriented mode of operation required a substantial increase in resources. To increase human resources, each organisation utilised external recruitment of appropriately trained and experienced people from the for-profit as well as the nonprofit arena. Existing employees were also trained or encouraged to upskill to some extent. These practices enable the new skills to be utilised to review and improve existing operations and service delivery. Each organisation took steps to increase operational funding sources - Darista via improved retail selling of second hand goods, Hestina via improved lottery selling, and Jantida via government grant sourcing. Volunteers were seen as a key resource within Darista, but Hestina, and moreso Jantida viewed volunteers as less of an appropriate resource. Jantida subsequently reduced their number of volunteers. Whilst Darista maintained viewing volunteers as a key resource, a problem was the aging of their volunteer base. Darista subsequently commenced promotion to University students to recruit new, younger volunteers resources.

Cost orientation was evident in two of the organisations with Darista re-structuring operations of the individual divisions to centralise various operations to reduce costs whilst Hestina rationalised and modified service delivery to simultaneously reduce cost and improve efficiency of services. 
Thus, overall, relatively high levels of all aspects of MO were identified in all three charities, and some levels of other strategic orientations were identified in various charities. Particularly notable was the need to focus upon increasing appropriate resources within each organisation, without which, the change to a more businesslike and market-oriented mode of operation would likely not have occurred.

\subsection{The implementation of change}

All three charities successfully introduced change into their organisations with the aim of improving performance in the face of increasing competition and demand for services. The result of the change is characterised by a strong MO as the new key strategic orientation. This is logical and in line with the rationale that a MO is regarded as the key strategic orientation linked to improving performance (Grinstein 2008). Associated with the increase in MO was introduction of aspects of other strategic orientations, particularly resource orientation that was identified as essential in providing the appropriate resources for the organisation to enable increased MO.

How did this organisational change occur? An examination of the discourse transformations identifies a three-phase process of change. Firstly, "new managerialism" occurred with specialist managers (typically newly recruited) directing the organisational changes. This was facilitated by introduction of new CEO's into each organisation (an increase in resources). Management techniques from the for-profit arena were introduced in keeping with the comments from various researchers that charities need to become more businesslike to survive (McDonald 2007). 
The next phase of change was introduction of "professionalism", which is often utilised as a key strategy for conducting organisational change (Evetts 2003), is associated with "change of the occupational role and work practices” (Evetts 2003, p. 29) and has been found to be positively correlated with MO (Hampton and Hampton 2004). This was a major discursive shift from traditional charity discourse characterised by use of volunteers. As exemplified within Jantida - “we're expecting more of our staff, we're expecting greater emphasis on training and people having the skills to do the job”. Up-skilling was offered to current paid employees, new professionally qualified employees were also recruited, and there was less use of volunteers. This increase in professionalism can also be viewed as an increase in resource.

The first two phases provided the foundations of knowledge and capabilities to enable the new discourse to subsequently be embedded into daily operations by appropriately knowledgeable employees. The “embedding” included review of existing operations and resultant introduction of new processes in both revenue generation and service delivery. For revenue generation, state-of-the-art practices from the for-profit arena were added (e.g. relationship marketing, direct marketing, targeting) and within service delivery, holistic, more effective and efficient processes were introduced to service client needs.

Thus, it was identified that a three-phase process of new managerialism, professionalism, then embedding was utilised to implement the discourse transformations within all three organisations. Based upon the insights gained from the study of organisational change within this paper, a "checklist" of key issues was developed and is contained in Table II. The issues are based upon themes identified during the thematic analysis of interview transcripts, the step-by-step activities taken by each organisation during the change, and the learnings (both positive and negative) mentioned by respondents based upon their experiences during the change process. The "checklist" is aimed to assist managers 
to successfully implement organisational change characterised by MO with appropriate complementing aspects of other strategic orientations. In developing the checklist, key issues identified during the analysis have been summarised and placed in a sequential order. Once the need to change is recognised, review of existing operations and resources is required. Obtaining appropriate resources and capabilities to progress and implement the change is also needed. In commencing the change, recognition that some employees may not like the changes and may leave needs to be recognised and accepted. During the change to new and improved service delivery and revenue sourcing, employees need to be constantly informed of the reasoning and rationale for the changes, and given appropriate training regarding the new ways of operating. If these key issues are progressed and addressed in a timely and thorough manner, successful introduction of MO can be achieved, resulting in increased organisational performance.

[Table II Here]

\section{Conclusions}

\subsection{Theoretical and Managerial Implications}

The paper has important implications for both theory and practice. Whilst there is extensive literature regarding commercial marketing (Kotzaivazoglou 2011), there is significantly less regarding the marketing of NPOs. Progressing research regarding MO within nonprofit organisations is appropriate and worthwhile as the findings can assist nonprofit organisations increase performance for the benefit of society. 
The paper expands empirical understanding as well as both academic and practitioner knowledge regarding exactly how organisational change can successfully be introduced into nonprofit organisations. Whilst there are strong philosophical views regarding the marketization of nonprofit organisations (Eikenberry 2009) and the tension between how nonprofit organisations balance efficiency versus their role as "important to democracy" (Brainard and Siplon 2004, p. 436), the paper provides support for the use of MO within charities to improve organisational performance for the benefit of service recipient clients via delivery of more specific and customised products better addressing client need. Other stakeholders such as revenue providers (e.g. government, corporations, individual donors) also benefit by seeing their financial inputs more effectively and efficiently utilised. Appropriate aspects of other strategic orientations including $\mathrm{RO}, \mathrm{EO}, \mathrm{LO} \& \mathrm{TO}$ can complement this key new strategic orientation to provide greater performance improvement than may occur had a purely MO been introduced. Indeed, it can be regarded that the increase in MO would not have been possible without the increase in RO - in the form of managerialism and professionalism.

The change management process was examined utilising a discourse transformation perspective, somewhat novel in examining the change process within charities and hence a key contribution. This ‘free-form’ process enabled drawing out identification of the phased process of change - new managerialism, professionalism, embedding and thus can be considered to provide more knowledge than could have been gained if using a pre-existing rigid model of change such as Lewin's (1951) change process model as previously used by Beverland and Lindgreen (2007) in examining MO within a for-profit setting.

The study reinforces and confirms previous statements that marketing practices from the for-profit sector can be transferred successfully into the nonprofit sector (e.g. Kotler and Andreasen 1996). A subtle difference however being that, initially the transfer of marketing 
practices requires "buy-in" from employees who are unfamiliar with the new mode of operation within nonprofit organisations. Once this is accepted, over time, it is indeed possible that marketing activities within the nonprofit sector may subsequently develop to the extent that these can then actually 'teach' for-profit marketers new ways of operating.

Management needs to be alert and aware when there is a need to change. Change can be driven by either visionary existing management (evolutionary change), or by new managers specifically employed to implement change (revolutionary change). Each organisation in this study required revolutionary change and subsequently increased performance via the introduction of new strategic orientations dominated by MO. Coupled with more efficient service delivery, increased revenue has enabled provision of extra services - benefiting multiple stakeholders and thus society overall.

Employees are more likely to commit to a leader if the leader's vision is similar to the values acceptable to the employees (Kotter 1995; Herold et al. 2008; Strebel 1996), thus successful implementation of change within the case organisations required management to conduct the change management process in a manner which was perceived as appropriate and meaningful to employees. The basis of organizational culture is collectively shared core values (Shiva and Suar 2012). Employees within traditional charities feel strongly for their service recipient clients. Thus, to assist smooth discourse transformation, 'articulation', a form of connection that can unite two elements under specific conditions (Hall, 1996) was utilised by management. The linkage between the old and the new discourse was improved service delivery, with management selling the change to employees upon the basis that the new mode of operating would result in better services for clients. Overall, the majority of employees accepted the new discourse. The manner in which change should be conducted can be summarised by a senior manage within Darista who indicated - "all charities need to be changing but without forgetting where they come from, without abandoning their mission. 
I think you can be a professional charity without abandoning [your] mission if it's managed correctly”.

The study responds to the call for research regarding how nonprofit organisations “can best build and maintain MO” (Shoham et al. 2006, p. 470) and similar calls from Harris (2000), Kennedy et al. (2003), Beverland and Lindgreen (2007) as well as Chad et al. (2013) to progress research into the manner in which $\mathrm{MO}$ is actually introduced into organisations. We identify however that such research should also examine possible existence of other strategic orientations, particular resource orientation. The study provides charity management with real-world knowledge regarding how change has been successfully introduced in existing charities and these learnings can be utilised within their own organisations to improve performance in their dynamic and competitive environment. In the face of increasing competition and demand for services, charities can no longer stay as traditional charities, they need to become more market-oriented and operate as businesses.

\subsection{Limitations and future research}

The findings in this research are specific to the charity context (albeit a vital component of society) within a single country. Examination of other charities of various sizes and in other geographic locations offers further research opportunities. Likewise, examination of organisations in other sub-sectors of the overall nonprofit sector would be worthwhile as there are likely to be unique aspects to charities that make the change process different within other nonprofit sub-sectors. The developed "checklist" offers guidelines for managers and future research can include more in-depth examination of these various activities, particularly within each of the phases of change. For example, what is the best way to introduce professionalism, is it via upskilling existing employees or simply buying-in new employees? 
Likewise, what is the best way to increase revenue, is it via expanding and improving upon existing revenue raising activities, or is it via introduction of entirely new activities? Previous research has examined various antecedents of MO. For example, Jaworski and Kohli (1993) identify top management, interdepartmental dynamics and organisational systems whilst in the nonprofit setting Sargeant, Foreman and Liao (2002) list mission, values, beliefs, goal congruence, systems and structures. The current research has now specifically identified as antecedents within the nonprofit charity context the need for new managerialism and professionalism before MO can be introduced. Future research can thus build upon these findings and involve revising current models describing antecedents of MO within nonprofit organisations. Such research should also include a resource orientation perspective given that many traditional nonprofit organisations may not currently have the resources to support becoming market-oriented. Also, whilst it is generally accepted that MO provides the most improvement in performance, further examination of what proportions of other strategic orientations aid performance can be investigated. 


\section{References}

Anheier, H. (2000). Managing non-profit organisations: Towards a new approach. Civil Society Working Paper 1, January 2000. Retrieved from http://eprints.lse.ac.uk/29022/1/cswp1.pdf.

Austin, M. (2003). The changing relationship between nonprofit organizations and public social service agencies in the era of welfare reform. Nonprofit \& Voluntary Sector Quarterly, 32 (1), 97-114.

Baker, W.E., \& Sinkula, J.M. (1999a). The synergistic effect of market orientation and learning orientation o norganisational performance. Journal of th eAcademy of Marketing Science. 27 (4), 411-427.

Baker, W.E., \& Sinkula, J.M. (1999b). Learning orientation, market orientation, and innovation: integrating and extending models of organisational performance. Journal of Market Focused Management, 4 (4), 295-308.

Baker, W.E., \& Sinkula, J.M. (2009). The complementary effects of market orientation and entrepreneurial orientation on profitability in small businesses. Journal of Small Business Management, 47 (4), 443-464.

Bennett, R., \& Sharmila, S. (2011), Surviving mission drift: How charities can turn dependence on government contract funding to their own advantage. Nonprofit Management \& Leadership, 22 (2), 217-231.

Beverland, M., \& Lindgreen, A. (2007). Implementing market orientation in industrial firms: A multiple case study. Industrial Marketing Management, 36 (4), 430-442.

Blery, E., Katseli, E., \& Tsara, N. (2010). Marketing for a non-profit organization. International Review on Public and Nonprofit Marketing, 7,57-68. 
Brainard, L., \& Siplon, P. (2004). Toward nonprofit organization reform in the voluntary spirit: Lessons from the internet. Nonprofit \& Voluntary Sector Quarterly, 33 (3), 435-457.

Calantone, R.J., Cavusgil, S.T., \& Zhao, Y. (2002). Learning orientation, firm innovation capability, and firm performance. Industrial Marketing Management, 31 (6), 515-524.

Cano, C.R., Carillat, F.A., \& Jaramillo, F. (2004). A meta-analysis of the relationship between market orientation and business performance: Evidence from five continents. International Journal of Research in Marketing, 21 (2), 179-200.

Chad, P., Kyriazis, E., \& Motion, J. (2013). Development of a market orientation research agenda for the nonprofit sector. Journal of Nonprofit \& Public Sector Marketing, 25 (1), 1-27.

Choi, S. (2012). Learning orientation and market orientation as catalysts for innovation in nonprofit organizations. Nonprofit \& Voluntary Sector Quarterly, online 21 Dec 2012 doi:10.1177/0899764012465491

Clohesy, W.W. (2003). Fund-raising and the articulation of common goods. Nonprofit \& Voluntary Sector Quarterly, 32, 128-140.

Connor, R. (1999). How responsive are charities to market needs? International Journal of Nonprofit and Voluntary Sector Marketing, 4 (4), 338-348.

Cornelissen, J., \& Lock, A. (2005). The uses of marketing theory: Constructs, research propositions, and meaningful implications. Marketing Theory, 5 (2), 165-184.

Costa, E., Ramus, T., \& Andreaus, M. (2011). Accountability as a managerial tool in nonprofit organizations: Evidence from Italian CSVs. VOLUNTAS: International Journal of Voluntary and Nonprofit Organizations, 22, 470-493. 
Covaleski, M.A., Dirsmith, M.W., Heian, J.B., \& Sajay, S. (1998). The calculated and avowed: Techniques of discipline and struggles over identity in the big six public accounting firms. Administrative Science Quarterly, 43 (2), 293-327.

Covin, J., \& Slevin, D. (1989). Strategic management of small firms in hostile and benign environments. Strategic Management Journal, 10, 75-87.

Creswell, J. (2003). Research design; Qualitative, quantitative, and mixed methods approaches (2nd ed.). Thousand Oaks, CA: Sage.

Damanpour, F. (1991). Organizational innovation: A meta-analysis of effects of determinants and moderators. Academy of management Journal,. 34 (3), 555-590.

Eikenberry, A. (2009). Refusing the market: A democratic discourse for voluntary and nonprofit organizations. Nonprofit \& Voluntary Sector Quarterly, 38 (4), 582-596.

Eisenhardt, K., \& Graebner, M. (2007). Theory building from cases: Opportunities and challenges. Academy of Management Journal, 50 (1), 25-32.

Evetts, J. (2003). The construction of professionalism in new and existing occupational contexts; Promoting and facilitating occupational change. International Journal of Sociology and Social Policy, 23 (4), 22-35.

Fischer, R.L., Wilsker, A., \& Young, D.R. (2011). Exploring the revenue mix of nonprofit organizations: Does it relate to publicness? Nonprofit \& Voluntary Sector Quarterly, $40(4), 662-681$.

Foucault, M. (1991). The Foucault Effect - Studies in Governmentality. London: Harvester Wheatsheaf.

Gainer, B., \& Padanyi, P. (2002). Applying the marketing concept to cultural organisations: An empirical study of the relationship between market orientation and performance. International Journal of Nonprofit and Voluntary Sector Marketing, 7 (2), 182-193. 
Gainer, B., \& Padanyi, P. (2005), The relationship between market-oriented activities and market-oriented culture: Implications for the development of market orientation in nonprofit service organisations. Journal of Business Research, 58 (6), 854-862.

Gatignon, H., \& Xuereb, J. (1997). Strategic orientation of the firm and new product performance. Journal of Marketing Research, 34 (1), 77-90.

Gebhardt, G., Carpenter, G., \& Sherry Jr., J. (2006). Creating a market orientation: A longitudinal, multifirm, grounded analysis of cultural transformation. Journal of Marketing, 70, 37-55.

Gewirtz, S., \& Ball, S. (2000). From 'Welfarism' to 'New managerialism': Shifting discourses of school headship in the education marketplace. Discourse, 21 (3), 253-268.

González, L.I.Á., Vijande, M.L.S., \& Casielles, R.V. (2002). The market orientation concept in the private nonprofit organisation domain. International Journal of Nonprofit and Voluntary Sector Marketing, 7(1), 55-67.

González-Benito, O., González-Benito, J., \& Muñoz-Gallego, P.A. (2009), Role of entrepreneurship and market orientation in firms' success. European Journal of Marketing, 43 (3), 500-522.

Grinstein, A. (2008), "The relationships between market orientation and alternative strategic orientations", European Journal of Marketing, 42 (1/2), 115-134.

Hakala, H. (2011). Strategic orientations in management literature: Three approaches to understanding the interaction between market, technology, entrepreneurial and learning orientations. International Journal of Management Reviews, 13 (2), 199-217.

Hall, S. (1996). On postmodernism and articulation: An interview with Stuart Hall. In L. Grossberg, D. Morley, \& K-H. Chen (Eds.), Stuart Hall: Critical dialogues in cultural studies, pp. 131-150, (reprinted from Journal of Communication Inquiry, 1986 Vol. 10, no. 2, pp. 45-60). London: Routledge. 
Hampton, G. \& Hampton, D. (2004). Relationship of professionalism, rewards, market orientation and job satisfaction among medical professionals: The case of certified nurse-midwives. Journal of Business Research, 57, 1042-1053.

Handy, F., Mook, L., \& Quarter, J. (2008). The interchangeability of paid staff and volunteers in nonprofit organizations. Nonprofit \& Voluntary Sector Quarterly, 37 (1), 76-92.

Harris, L.C. (2000). The organisational barriers to developing market orientation. European Journal of Marketing, 34 (5/6), 598-624.

Harris, L.C., \& Ogbonna, E. (2001). Strategic human resource management, market orientation, and organisational performance. Journal of Business Research, 51 (2), 157-166.

Harris, L.C., \& Piercy, N. (1999). Management behaviour and barriers to market orientation in retailing companies. The Journal of Services Marketing, 13 (2), 113-131.

Herold, D.M., Fedor, D.B., Caldwell, s., \& Liu, Y. (2008). The effects of transformational and change leadership on employees' commitment to a change: A multilevel study. Journal of Applied Psychology, 92 (2), 346-357.

Hestina (2006). Annual report 2005/6.

Hestina (2007). Annual report 2006/7.

Hestina (2008). Annual report 2007/8.

Hsieh, J., Curtis, K. P., \& Smith, A. W. (2008). Implications of stakeholder concept and market orientation in the US nonprofit arts context. International Review on Public and Non-Profit Marketing, 5(1), 1-13.

Hurley, R.F., \& Hult, T.M. (1998). Innovation, market orientation, and organizational learning: An integration and empirical examination. Journal of Marketing, 62 (July), $42-54$. 
Homburg, C., Workman, J., \& Krohmer, H. (1999). Marketing's influence within the firm. Journal of Marketing, 63 (April), 1-17.

Jaskyte, K., Byerly, C., Bryant, A., \& Koksarova, J. (2010). Transforming a nonprofit work environment for creativity: An application of concept mapping. Nonprofit Management \& Leadership, 21 (1), 77-92.

Jaworski, B.J. \& Kohli, A.K. (1993). Market orientation: Antecedents and consequences. Journal of Marketing, 57 (3), 53-70.

Jones, L. (2000). Market orientation - A case study of three UK opera companies. International Journal of Nonprofit and Voluntary Sector Marketing, 5 (4), 348-364.

Kennedy, K., Goolsby, J., \& Arnould, E. (2003). Implementing a customer orientation: Extension of theory and application. Journal of Marketing, 67 (4), 67-81.

Kara, A., Spillan, J.E., \& DeShields, Jr. O.W. (2004). An empirical investigation of the link between market orientation and business performance in non-profit service providers. Journal of Marketing Theory and Practice, 12 (2), 59-71.

King, N. (1990). Modelling the innovation process: An empirical comparison of approaches. Journal of Occupational and Organisational Psychology, 65 (2), 89-101.

Kinnell, M., \& MacDougall, J. (1997). Marketing in the Not-For-Profit Sector. Oxford, Butterworth-Heinemann.

Kirca, A., Jayachandran, S., \& Bearden, W. (2005). Market orientation: A meta-analytic review and assessment of its antecedents and impact on performance. Journal of Marketing, 69 (April), 24-41.

Kotler, P., \& Andreasen, A. (1996). Strategic marketing for nonprofit organizations, (5th ed.). Upper Saddle River, NJ: Prentice-Hall.

Kotzaivazoglou, I. (2011). Political marketing in the Greek context: Does market orientation exist? International Review on Public and Nonprofit Marketing, 8, 41-56. 
Kumar, V., Jones, E., Venkatesan, R., \& Leone, R. (2011). Is market orientation a source of sustainable competitive advantage or simply the cost of competing? Journal of Marketing, 75 (Jan), 16-30.

Kohli, A.K., \& Jaworski, B.J. (1990). Market orientation: The construct, research propositions, and managerial constructs. Journal of Marketing, 54 (2), 1-18.

Kotter, J.P. (1995). Leading change: Why transformation efforts fail. Harvard Business Review, March-April, 59-67.

Kreutzer, K., \& Jäger, U. (2011). Volunteering versus managerialism: Conflict over organizational identity in voluntary associations. Nonprofit \& Voluntary Sector Quarterly, 40, 634-661.

Lafferty, B.A , \& Hult, G.T.M. (2001). A synthesis of contemporary market orientation perspectives. European Journal of Marketing, 35 (1/2), 92-109.

LeCompte, M.D. \& Preissle, J. (1993). Ethnography and qualitative design in educational research. San Diego, CA: Academic Press.

Lewin, K. (1951). Field theory in social science. New York, NY: Harper \& Row.

Liao, M-N., Foreman, S.\& Sargeant, A. (2001). Market versus societal orientation in the nonprofit context. International Journal of Nonprofit and Voluntary Sector Marketing, 6 (3), 254-268.

Liu, B., \& Fu, Z. (2011). Relationship between strategic orientation and organizational performance in born global: a critical review. International Journal of Business and Management, 6 (3), 109-115.

Liu, G., Takeda, S., \& Ko, W-W. (2012). Strategic orientation and social enterprise. Nonprofit \& Voluntary Sector Quarterly, online 21 Dec 2012. doi:10.1177/0899764012468629. 
Lumpkin, G.T., \& Dees, G.G. (1996). Clarifying the entrepreneurial orientation construct and linking it to performance. Academy of Management Review, 21, 135-172.

Malhotra, N.K. (2007). Marketing Research: An applied Orientation. Upper Saddle River, NJ: Pearson.

Mason, K., \& Harris, L.C. (2005). Pitfalls in evaluating market orientation; an exploration of executives' interpretations. Long Range Planning, 38 (4), 373-391.

McDonald, R.E. (2007). An investigation of innovation in nonprofit organizations: The role of organizational mission. Nonprofit \& Voluntary Sector Quarterly, 36 (2), 256-281.

Meyer, M., Buber, R., \& Aghamanoukjan, A. (2013). In search of legitimacy: Managerialism and legitimation in civil society organizations, VOLUNTAS: International Journal of Voluntary and Nonprofit Organizations, 24, 167-193.

Modi, P. (2012). Market orientation in nonprofit organizations: Innovativeness, resource scarcity, and performance. Journal of Strategic Marketing, 20 (1), 55-67.

Modi, P., \& Mishra, D. (2010). Conceptualising market orientation in non-profit organisations: Definition, performance, and preliminary construction of a scale", Journal of Marketing Management, 5, 548-569.

Mahmoud, A. M., \& Yusif, B. (2012). Market orientation, learning orientation, and the performance of nonprofit organisations (NPOs). International Journal of Productivity and Performance Management, 61 (6), 624-652.

Naman, J. \& Slevin, D.P. (1993). Entrepreneurship and the concept of fit: a model and empirical tests', Strategic Management Journal, 14 (2), 137-153.

Narver, J.C., \& Slater, S.F. (1990). The effect of a market orientation on business profitability. Journal of Marketing, 54 (4), 20-35. 
Noble, C.H., Sinha, R.K., \& Kumar, A. (2002). Market orientation and alternative strategic orientations: A longitudinal assessment of performance implications. Journal of Marketing, 66 (October), 25-39.

Olson, E., Slater, S.F., \& Hult, G.T.M. (2005). The performance implications of fit among business strategy, marketing organization structure, and strategic behavior. Journal of Marketing, 69 (3), 49-65.

Padanyi, P., \& Gainer, B. (2004). Market orientation in the nonprofit sector: Taking multiple constituencies into consideration. Journal of Marketing Theory and Practice, 12 (2), 43-58.

Paladino, A. (2006). Understanding the drivers of corporate performance and customer value. In M. Epstein, \& J-F. Manzoni (Eds), Studies in Managerial and Financial Accounting Volume 16. Performance Measurement and Management Control: Improving Organizations and Society. pp.131-155. Oxford: Elsevier.

Paladino, A. (2007). Investigating the drivers of innovation and new product success: A comparison of strategic orientations. Product Innovation Management, 25, 534-553.

Patton, M. (2002). Qualitative research \& evaluation methods (3rd ed.). Thousand Oaks, CA: Sage.

Raju, P., Lonial, S., \& Crum, M. (2011). Market orientation in the context of SMEs: A conceptual framework. Journal of Business Research, 64, 1320-1326.

Ramani, G., \& Kumar, V. (2008). Interaction orientation and firm performance. Journal of Marketing, 72 (January), 27-45.

Rapert, M., Velliquette, A., \& Garretson, J. (2002). The strategic implementation process: Evoking strategic concensus through communication. Journal of Business Research, 55, 301-310. 
Ridder, H-G., \& McCandless, A. (2010). Influences on the architecture of human resource management in nonprofit organizations: An analytical framework. Nonprofit \& Voluntary Sector Quarterly, 39 (1), 124-141.

Ridder, H-G., Piening, E.P., \& McCandless Baluch, A. (2012). The third way reconfigured: How and why nonprofit organizations are shifting their human resource management, VOLUNTAS: International Journal of Voluntary and Nonprofit Organizations, 23, 605-635.

Salamon, L.M. (1987). Of market failure, voluntary failure, and third-party government: Toward a theory of government-nonprofit relations in the modern welfare state. Nonprofit \& Voluntary Sector Quarterly, 16, 29-49.

Sargeant, A. (2001). Using donor lifetime value to inform fundraising strategy. Nonprofit Management \& Leadership, 12 (1), 25-38.

Sargeant, A., Foreman, S., \& Liao, M-N. (2002). Operationalizing the marketing concept in the nonprofit sector. Journal of Nonprofit \& Public Sector Marketing, 10 (2), 41-65. Shields, P.O. (2009). Young adult volunteers: Recruitment appeals and other marketing considerations. Journal of Nonprofit and Public Sector Marketing, 21 (2), 139-159.

Shiva, M.S.A.M., \& Suar, D. (2012). Transformational leadership, organizational culture, organizational effectiveness, and programme outcomes in non-governmental organizations, VOLUNTAS: International Journal of Voluntary and Nonprofit Organizations, 23, 684-710.

Shoham, A., Rose, G.M., \& Kropp, F. (2005). Market orientation and performance: A meta analysis. Marketing Intelligence and Planning, 23 (5), 435-454.

Shoham, A., Ruvio, A., Vigoda-Gadot, E., \& Schwabsky, N. (2006). Market orientations in the nonprofit and voluntary sector: A meta-analysis of their relationships with 
organizational performance. Nonprofit \& Voluntary Sector Quarterly, 35 (3), 453476.

Sinclair, A. (1996). Leadership in administration: Rediscovering a lost discourse. In P. Weller, \& G. Davies (Eds.), New ideas, better government. St Leonards: Allen \& Unwin.

Sinkula, J.M., Baker, W., \& Noordewier, T.G. (1997). A framework for market-based organizational learning: Linking values, knowledge and behavior. Journal of the Academy of Marketing Science. 25 (Fall), 305-318.

Strebel, P. (1996). Why do employees resist change? Harvard Business Review, May-June, 86-92.

Taghian, M. (2010). Marketing planning: Operationalising the market orientation strategy. Journal of Marketing Management, 26 (9), 825-841.

Tesch, R. (1990). Qualitative research: Analysis types and software tools. New York, NY: Falmer.

Van Raaij, E., \& Stoelhorst, J. (2008). The implementation of a market orientation: A review and integration of the contributions to date. European Journal of Marketing, 42 (11/12), 1265-1293.

Vickers, M., \& Kouzmin, A. (2001) New managerialism and Australian police organisations. The International Journal of Public Sector Management, 14 (1), 7-26.

Waldon, G.I. (2005). Who's watching us now? The nonprofit sector and the new government of surveillance. Nonprofit \& Voluntary Sector Quarterly, 35, 715-720.

Wood, L.A., \& Kroger, R.O. (2000). Doing discourse analysis: Methods for studying action in talk and text. Thousand Oaks, CA: Sage. 
Yakimova, R., \& Beverland, M. (2005). The brand-supportive firm: An explanation of organisational drivers of brand updating. Journal of Brand Management, 12 (6), 445460.

Yin, R.K. (1994). Case study research - Design and methods (2nd ed.). Thousand Oaks, CA: Sage.

Table I- Key Aspects of the three charities

\begin{tabular}{|c|c|c|c|}
\hline & Darista & Hestina & Jantida \\
\hline $\begin{array}{l}\text { Years of } \\
\text { operation }\end{array}$ & 150 & 60 & 160 \\
\hline $\begin{array}{l}\text { Paid } \\
\text { Employees }\end{array}$ & 1,350 & 100 & $\begin{array}{l}1,400 \\
1,500 \text { (5 years later) }\end{array}$ \\
\hline $\begin{array}{l}\text { Volunteer } \\
\text { Employees }\end{array}$ & $\begin{array}{l}24,000 \\
\text { Average of } 92 \text { hours per } \\
\text { year per volunteer. }\end{array}$ & 40 & $\begin{array}{l}2,000 \\
\text { Average of } 200 \text { hours } \\
\text { per year per volunteer. } \\
1,000 \text { ( } 5 \text { years later })\end{array}$ \\
\hline $\begin{array}{l}\text { Main } \\
\text { revenue } \\
\text { sources }\end{array}$ & $\begin{array}{l}\text { Retail stores } 49 \% \\
\text { Govt 23\% } \\
\text { Donations 11\% } \\
\text { Other } 8 \% \\
\text { Bequests 6\% }\end{array}$ & $\begin{array}{l}\text { Lottery ticket sales 62\% } \\
\text { Donations } 26 \% \\
\text { Government } 4 \%\end{array}$ & $\begin{array}{l}\text { Government 54\% } \\
\text { Interest 16\% } \\
\text { Donations 11\% } \\
\text { Clients 11\% } \\
\text { Retail stores 5\% } \\
\text { Govt \& clients 86\% (5 } \\
\text { years later) }\end{array}$ \\
\hline $\begin{array}{l}\text { Annual } \\
\text { Income }\end{array}$ & A\$122 million & $\begin{array}{l}\text { A } \$ 3.5 \text { million } \\
\text { A } \$ 7 \text { million (4years } \\
\text { later) }\end{array}$ & $\begin{array}{l}\text { A } \$ 70 \text { million } \\
\text { A } \$ 99 \text { million (5 years } \\
\text { later) }\end{array}$ \\
\hline
\end{tabular}


Table II- Managerial “Checklist” of key issues to assist successful implementation of organisational change based upon market orientation

\begin{tabular}{|c|c|c|c|}
\hline \multirow[b]{2}{*}{ Activity } & \multicolumn{3}{|c|}{ Stage } \\
\hline & $\begin{array}{c}\text { New } \\
\text { Managerialism }\end{array}$ & Professionalism & Embedding \\
\hline $\begin{array}{l}\text { Be proactive in recognising the need for } \\
\text { change. }\end{array}$ & $\checkmark$ & & \\
\hline $\begin{array}{l}\text { Review existing service delivery and } \\
\text { revenue generation. }\end{array}$ & $\checkmark$ & $\checkmark$ & \\
\hline $\begin{array}{l}\text { Introduce new managerialism and } \\
\text { professionalism. (Including external } \\
\text { resource sourcing if required). }\end{array}$ & $\checkmark$ & $\checkmark$ & \\
\hline Accept that some employees may resign. & $\checkmark$ & $\checkmark$ & \\
\hline $\begin{array}{l}\text { Emphasise to employees the need for } \\
\text { change - for survival - and the resultant } \\
\text { net benefits for all stakeholders, } \\
\text { particularly service recipients - enabling } \\
\text { a win-win situation. }\end{array}$ & $\checkmark$ & $\checkmark$ & $\checkmark$ \\
\hline $\begin{array}{l}\text { Leverage existing resources and } \\
\text { capabilities and buy-in new required } \\
\text { capabilities. }\end{array}$ & & $\checkmark$ & \\
\hline Up-skill existing employees. & & $\checkmark$ & \\
\hline $\begin{array}{l}\text { Diversify revenue sources (e.g. explore } \\
\text { social entrepreneurialism and } \\
\text { government funding possibilities). }\end{array}$ & & $\checkmark$ & $\checkmark$ \\
\hline $\begin{array}{l}\text { Adjust the organisational view of service } \\
\text { recipient clients, namely adopt a holistic } \\
\text { rather than "band-aid" perspective of } \\
\text { service delivery (for improved outcomes } \\
\text { and efficiency) }\end{array}$ & & $\checkmark$ & $\checkmark$ \\
\hline $\begin{array}{l}\text { Introduce change at a rate at which } \\
\text { employees can "assimilate" and also } \\
\text { understand the changes. }\end{array}$ & & $\checkmark$ & $\checkmark$ \\
\hline $\begin{array}{l}\text { Ensure employees understand the new } \\
\text { "language of business" utilised by } \\
\text { management. }\end{array}$ & & $\checkmark$ & $\checkmark$ \\
\hline $\begin{array}{l}\text { Utilise ongoing and regular } \\
\text { communication and dialogue with } \\
\text { employees. }\end{array}$ & & $\checkmark$ & $\checkmark$ \\
\hline $\begin{array}{l}\text { Involve employees throughout all stages } \\
\text { of the change (e.g. planning days, cross- } \\
\text { functional committees/teams). }\end{array}$ & & $\checkmark$ & $\checkmark$ \\
\hline $\begin{array}{l}\text { Introduce best-practice marketing } \\
\text { techniques from the for-profit sector (e.g. } \\
\text { direct marketing, customer life-time } \\
\text { value, customer segmentation). }\end{array}$ & & & $\checkmark$ \\
\hline Be aware of new required roles for & & & $\checkmark$ \\
\hline
\end{tabular}


employees.

Maintain a client first ethos, albeit via a

new service delivery process.

\section{Appendix I- Interview Questions for Charity Employees}

\section{YOUR ROLE}

1. What is your role in the organisation and how long have you been with the organisation?

2. What does your job entail?

3. What is your background? (training, previous employment etc.)

4. Tell me about the current purpose of your organisation.

\section{MACRO-CHANGE}

1. How would you describe a 'traditional' old-fashioned charity?

2. What do you see as the key differences between a nonprofit charity and a for-profit business organisation?

3. Can traditional charities survive in this day and age? If not, how do they need to change?

4. What changes have management introduced here in recent years and what has been the effect?

5. What caused these changes?

6. How did the existing staff feel about these changes occurring?

7. Were the changes gradual or rapid? How were they introduced?

8. Did / has your role, way of working changed?

9. Can you tell me a story about when "the changes were positive", "the changes raised problems”?

10. What are the key differences between the organisation now, compared with say X years ago before the changes were introduced? 
11. What does the word 'marketing' mean to you?

12. What happens when you talk about 'marketing' in your organisation. What is the reaction of staff?

13. Has the way you talk about/within the organisation changed? E.g. Has the language changed

14. When various new commercial practices were introduced - how did you feel about these?

15. How is the 'performance' of the organisation 'measured'?

\section{STAKEHOLDERS}

1. What sort of rewards do employees receive/want? Does it vary between paid and volunteer staff?

2. Is there more satisfaction working for a NFP organisation?

\section{$\underline{\text { MICRO }}$}

Market orientation - Adapted from Lafferty \& Hult (2001)

\section{Importance of information}

1. How does your organisation gather information regarding the industry, competitors, potential and current members?

2. To what extent is information analysed and shared within your organisation?

3. How well is information and decisions communicated within the organisation?

\section{Emphasis on customer}

1. How important is the donor client and the service recipient client to your organisation?

\section{Interfunctional co-ordination}

1. Does your organisation operate in a highly departmentalised fashion? How well do different departments get on?

2. Are different departments willing to consider and discuss ideas from other departments?

3. How much communication (both formal and informal) is there between departments? 
4. Is decision-making centralised of de-centralised?

\section{Taking action}

1. How have your service delivery methods and measures of quality changed in recent years?

\section{Entrepreneurial - Adapted from Naman \& Slevin (1993)}

1. Do you introduce many new services? How much time and effort would be involved in developing a new service?

2. How proactive would you regard your organisation within the industry in which you operate? Would you be regarded as a leader within the sector? If so, in which ways?

3. Is there much competition within the sector? How do you react to this competition?

Learning - Adapted from Calantone, Cavusgil \& Zhao (2002); Sinkula, Baker \& Noordewier $\underline{(1997)}$

1. Are employees encouraged to think outside the box?

2. Do many employees undertake training courses?

3. Does management share their vision of the organisation with all levels?

4. What happens when employees suggest new ideas of ways of doing business?

5. Does the organisation have a suggestion box?

Innovation - Adapted from Hurley and Hult (1998)

1. How actively does management seek innovative ideas?

2. How open are management to new and innovative ideas?

$\underline{\text { Resource - Adapted from Paladino (2007) }}$

1. What resources does your organisation have, and how unique are they compared to your competitors?

2. How well are resources shared between functional areas?

3. Do you think your organisation is using all its resources effectively? 


\section{Technological - Adapted from Gatignon \& Xuereb (1997)}

1. What type of technology, if any, does your organisation use? What is it used for?

2. What new products (particularly services) have you developed and introduced in recent years?

Cost - Adapted from Homburg, Workman and Krohmer (1999)

1. How important is reducing costs for your organisation?

\section{Final questions}

1. Can modern marketing methods used by for-profit companies be used by charities?

2. What makes charities successful? What do they do well - or not do well?

3. What are the characteristics of a successful charity?

4. How would you describe/interpret success for the organisation?

5. 'Growth' is there a limit? Or is all growth good? 